Egyptian J. of Nutrition Vol. XXXV No. 2 (2020)

\title{
Quinoa Grain to Improve the Nutritive Value and Functional Ingredient for Breadsticks
}

\author{
*Lamia. M .Lotfy $\quad{ }^{* * M o n a . ~ E . M . N a g a ~}$ \\ *Home Economics Department, Faculty of Specific Education, \\ Kafr-elsheikh University \\ ${ }^{* *}$ Home Economics. Department, Faculty of Specific Education, \\ Menoufia University
}

\section{Abstract}

This investigation aimed to substitute wheat flour (72\%) extraction with milled quinoa flour to breadsticks improve quality. The chemical composition of quinoa flour and wheat flour (72\%) were determined, then added quinoa to wheat flour(72\%) at levels of 5,10 , 15 , or $20 \%$. The results revealed that ether extract of quinoa flour had high amount of unsaturated fatty acids including the essential fatty acids such as oleic, linoleic or erucic acids. The obtained results showed that as the level of substitution increase, all components increased except total carbohydrates. The nutritive value of breadsticks enhanced due to the content of unsaturated fatty acids (oleic acid $\omega 9$ and linoleic acid $\omega 6$ ) in quinoa flour.Sensory evaluation of the produced of breadsticks, and the chemical ingredients of product and energy value $(\mathrm{Cal} / 100 \mathrm{~g})$ were determined 


\section{Introduction}

Quinoa flour is showing appropriate nutritional and functional properties due to its high quality protein with a wide amino acid spectrum, particularly rich in lysine. Quinoa is oldest cultivated grain in the world.Quinoa is high in protein,calcium and iron.You can substitute this flour for $1 / 2$ of the all-purpose flour in many recipes. Consequently, considering appropriate nutritional and functional properties of quinoa protein, it can be considered as a good candidate to supply human food products(Food Chem.2019).

Quinoa flour used from desserts to muffins to breads. The protein in quinoa flour helps to give your bread same structure, and will improve the overall texture.it's too high in carbos for keto diet and also has a high glycemic index- (Haros et al .,2017 and Ballester-sanchez et al .,2019).

Quinoa flour in formulations increase the protein content but it could also improve the biological value of the proteins in these formulations, since quinoa proteins contribute essential amino acids that are limiting in wheat flours (such as lysine and threonine), and they are more digestible (Vega-Galvez et al.,2010). It could also lead to an increase in the unsaturated fatty acid content and an improvement in the omega 3/omega 6 fatty acid relationship. The main unsaturated fatty acids in quinoa are linoleic and $\alpha$-linolenic acids, which are essential fatty acids (Repo-Carrasco and Sevna.,2013) . Moreover, its high fiber and mineral contents could help to attain the daily requirements of these substances and of calcium, iron and zinc in the diet (Haros et al .,2017 and BallesterSanchez et al .,2019) ). Quinoa is significantly known as a high protein source (more than 15\%), and balanced amino acid composition compared to the major cereals (Oshodi et al 2013)with 
Egyptian J. of Nutrition Vol. XXXV No. 2 (2020)

higher content of lysine (5.1-6.4\%) and methionine (0.4-1.0\%) (Bhrgava et all 2013). It contains a considerable amount of fiber and minerals Ando et al (2013). Quinoa contains large amount of Flavonoids,including quercetin and kaempferol.These are potent antioxidants numerous health benefit.Quinoa is also rich in antioxidants such as polyphenols (Repo-Carroso et al 2011). It has the highest content of its bioactive compounds compared to other cereal and pseudocereal crops (Hirosey-Fujta et al 2010).

Quinoa flour has perfect-balanced ingredients such as minerals (potassium, sodium, magnesium and calcium as well as even soluble iron). It has different kinds of vitamins such as B3, B6, $\mathrm{B} 9$, and $\mathrm{C}$ that are vital for human metabolism and prevention of several diseases.Quinoa is very high in minerals, phytic acid ,but its can partly prevent them from being absorbed .Soaking or Sprouting degrades most of the phytic acid. Its natural antioxidants such as phenolic compounds and flavonoids are helpful in treatment of degenerative diseases, water and oil absorptions of quinoa flour were favorably sound, which enhances its potentiality in human food and drinks formulations. Foaming as well as emulsion capacities and stabilities prove the importance of quinoa seeds flour to be used as a food additive/ingredient in food processing for its manufacturing quality. The high digestibility of quinoa flour protein was (86.85 \pm $0.83 \%$ ) which is supporting its high availability and digestibility in the human stomach and consequently its benefits for human health. ( EI Sohaimy et al.,2018).

The nutrient composition of quinoa is very good compared with common cereals (Demir, 2014). Quinoa seeds contains about from $1.8 \%$ to $9.5 \%$ oil (Vega-Gálvez et al., 2010).). Thus, it is a good supplement for legumes, which are ordinarily low in cysteine and 


\section{Lamia. M .Lotfy and Mona. E.M.Naga}

methionine. Some types of wheat come close to matching quinoa's protein content, but grain such as barley, corn and rice generally have less than half the protein content of quinoa have vitamins ( $B$ complex and $\mathrm{C}, \mathrm{E}$ ), important minerals (potassium, magnesium, calcium, iron, phosphorus, manganese) and high quality lipids (VegaGálvez et al., 2010 and Miranda et al., 2012).

Quinoa is much higher in fiber that most grains. One study found $17.27 \mathrm{gm}$ of fiber per cup (185 gms).Most of the fiber is insoluble, but one cup of quinoa still contains $2.5 \mathrm{gms}$ oh insoluble fiber.

Polyphenols are bioactive secondary plant metabolites that are widely present in particularly eaten foods of plant origin. The three major types of polyphenols are phenolic acids, flavonoids and tannins, which are act as powerful antioxidants in vitro. These components are reflect to have many potential serviceable health effects, containing antioxidant, apoptotic, anti-aging, anticarcinogenic and anti-inflammatory activities, cardio vascular protection and improvement of endothelial function. Polyphenols also inhibit angiogenesis and cell proliferation (Han et al.2007).

The purpose of this research was to determine the quinoa chemical composition and its essential fatty acids in comparison to the flour of common cereals (wheat flour $72 \%$ ).

\section{Materials and Methods}

\section{Chemical composition:}

Moisture, protein, ether extract and ash were determined according to the methods of the A.O.A.C (2000).While total 
Egyptian J. of Nutrition Vol. XXXV No. 2 (2020)

carbohydrates were estimated by subtracting from initial weight of the sample as follow:

$\%$ carbohydrates $=100-(\%$ crude protein $+\%$ crude fat+ $\%$ ash $)$.

Determination fatty acids composition:

Fatty acids composition of quinoa oil was determined using "gas chromatography" according to the method described by Radwan(1978).

\section{Breadsticks making:}

Preparation of sticks using quinoa flour by ingredients shown Table (1). Quinoa flour milled to obtain quinoa flour was substituted the base flour at different level (5, 10, 15 and $20 \%)$. The control dough was prepared form $100 \%$ wheat flour (72\% extraction).

The straight dough procedure was used for breadsticks making as follow: sugar, fat, salt and dry yeast, were added to each types of flour with warm water and oil, the ingredients were thoroughly mixed together manually. Dough was left to ferment for 30 min at room temperature (30 $\left.\pm 2{ }^{\circ} \mathrm{C}\right)$. Dough was divided into pieces and left $10 \mathrm{~min}$ to rest. The fermented pieces were shaped to the final form and fermented for $1 / 2$ hour at $30^{\circ} \mathrm{C}$ and $90 \%$ relative humidity. Fermented snacks dough's were baked at $170 \stackrel{\circ}{\circ}$ for $30 \mathrm{~min}$ (Ballester-Sánchez.,2019).

\section{Sensory evaluation:}

Organoleptic evaluation of the studied breadsticks with and without quinoa flour (quinoa flour) carried out by ten panelists to evaluate flavor, texture, color, taste and overall acceptability. The evaluations were made using scores from 1 to 10 , where excellent (10-9), very good (8-6), fair (5-4) and not acceptable (3-2) according to the Renzo (1975). 
Lamia. M .Lotfy and Mona. E.M.Naga

\section{Results and Discussion}

The chemical composition of quinoa flour and wheat flour $72 \%$ ( $g / 100 \mathrm{~g}$ on dry weight basis).

Results presented in table (2) show the chemical composition of quinoa seed and wheat flour ( $72 \%$ extraction) on dry weight basis.

From these data it could be noticed that quinoa seeds had the highest values in crude protein (13.13\%), ether extract (6.52\%), and ash $(4.65 \%)$. On the other hand total carbohydrate of wheat flour (72\% extraction) was $85.73 \%$ comparing with quinoa flour $(75.70 \%)$.

These results for quinoa flour are in agreement with Demir and Kilinc(2017) they found that quinoa flour contain $14.45 \%$ crude protein, $5.82 \%$ crude fat and 2.82 ash. Also. Demir and Kilinc (2017) showed that chemical composition of wheat flour $72 \%$ extraction that contained $9.52 \%$ crude protein $0.51 \%$ crude fat and $0.63 \%$ ash.We are found that our results on quinoa seeds and flour is not significant with Demir and Kilinc (2017) these results may be due to different percentage of essential amino acids and may be different of crud fiber.Quinoa is much higher in fiber than most grains.Most of the fiber is in soluble.

Saturated fatty acids content of quinoa flour $(\% \mathrm{~g}$ total fatty acids)

Saturated fatty acids composition of quinoa seed (\%g total fatty acids) was given in table ( 3 ). The dietary quinoa oil consisted mainly of stearic acid (34.432\%), palmitic acid (8.751\%), arachidic acid $(0.857 \%)$ with small concentrations of tridecylic acid ,myristic acid and pentadecylic acid. These results for are in partial agreement with Masson and Mella(1985) who reported that 
Egyptian J. of Nutrition Vol. XXXV No. 2 (2020)

unsaturated fatty acids composition of crude fat of quinoa seed contained myristic, palmetic, stearic acid which were 0.1-2.4, 9.211.2 and 0.6-1.1 \% respectively. Also, Calderelli et al.,(2010) stated that saturated fatty acids of quinoa seeds were myristic $(0.17 \%)$, plamtic (9.82\%) and steraic (1.47\%).

Unsaturated fatty acids content of quinoa seed (\%g total fatty acids).

Unsaturated fatty acids content of quinoa seed (\%g total fatty acids) are shown in table (4) the dietary quinoa oil consisted mainly of linoleic acid (34.429\%), oleic acid (18.0\%), erucic acid (1.0579\%) with small concentrations of eicosenoic acid and docosadienoic acid. These results are in partial agreement with Masson and Mella(1985) who reported that unsaturated fatty acids composition of crude fat of quinoa seed contain oleic acid (22.8-29.5), myristoleic acid (1\%), palmitoleic acid (0.2-1.2\%), linoleic acid (48.1-52.3\%) and linolenic acid (4.6-8\%). Also, Calderelli et all (2010) found that unsaturated fatty acids of quinoa seeds were oleic acid (29.90\%), linoleic acid (48.80\%) ,linolenic acid (7.34\%) and eicosenoic acid $(1.53 \%)$.

No risk form erucic acid given in table (4) which amounted of $1.06 \%$ of total unsaturated fatty acids ; being $1.0579 \%$ of fatty acids in quinoa seed used at no more $20 \%$ in bread sticks. Health hazard is for children only (not adults), up to 10 years age. This occurs only if level of C22:1 exceeds $2 \%$ of total fatty acid in food (FSAN,2003) .Quinoa contains large amounts of flavonoids,and large amounts minerals, but its phytic acid can portly prevent them from being absorbed.But when Soaking degrades most of the phytic acid.They found that using quinoa instead of Typical gluten free bread,and pasts significantly reduce blood sugar, insulin and triglyceride levels. 


\section{Lamia. M .Lotfy and Mona. E.M.Naga}

\section{Chemical composition of produced breadsticks}

From the obtained results in Table ( 5 ), it could be noticed that chemical composition of breadsticks produced from $100 \%$ wheat flour $(72 \%)$ extraction were as following: ether extract $(1.25 \%)$, crude protein $(11.75 \%)$, ash $(0.55 \%)$, total carbohydrate $(85.45 \%)$ and energy value were $(404.05 \mathrm{Cal} / 100 \mathrm{~g})$. Regarding the chemical composition of produced breadsticks with $5,10,15,20 \%$ substitution of quinoa flour ,it was found that all components increased, except total carbohydrate which were decreased. These results are in agreement with Abdullah et al.,(2016) reported that all components (ash, protein and ether extract) increased in molded bread made from wheat flour with quinoa flour at levels 5,10 or $20 \%$ except total carbohydrate which decreased. Quinoa contains relatively high concentration of tannins, Oxalates, and phytates. These natural substances many bind-proteins,enzymes, minerals and trace elements,reducing nutrient uptake.

\section{Organoleptic properties of bread sticks produced from wheat flour $(72 \%)$ and different levels of quinoa flour.}

Table (6 ) showed organoleptic properties of bread sticks produced from wheat flour (72\%) and different levels of quinoa flour . It could be observed that sample of bread sticks $100 \%$ wheat flour $(72 \%)$ were excellent of acceptability against all parameters, and sticks recorded very good grade against all samples produced from different levels of quinoa flour.These results me be due to protein in quinoa flour helps to give your breadsticks some structure and well improve the overall texture and also a healthier alternative to carbohydrates like rice or other grains.Still,it is too high in carbohydrates for the Keto diet and also a high glycemic index. From Table (6) addition 20\% Quinoa flour lead to low- glycemic-index carbohydrats since its very rich in fiber and protein. 
Egyptian J. of Nutrition Vol. XXXV No. 2 (2020)

This means you will feel fuller longer after consuming it which may help you eat less over time.Why we do not add more than $20 \%$ because.The only likely side effect is just some stomach irritation as a result of the saponin but easily prevented before eating rinse and soaking.

The sensory properties of bread sticks added to its surface are quinoa seeds produced from wheat flour $(72 \%)$ and different levels of quinoa flour.

The results concerning organoleptic properties of bread sticks produced from wheat flour (72\%) and different levels of milled quinoa seeds flour were illustrated in table $(7)$. It could be observed that sample of bread sticks which made from $100 \%$ wheat flour $(72 \%)$ showed the highest in acceptability for all parameters while had very good grade against all samples produced from different levels of quinoa flour. These results are in agreement with Abdullah et al.,(2016) who showed that samples prepared from wheat flour or those with 5,10 or $20 \%$ quinoa flour blends had good properties to make molded bread and had satisfactory and acceptable organoleptic evaluation .

From these results refers that.Quinoa is high in protein,calcium and iron.It can use this delicate flour when baking, and also contains all the essential amino acids that you neeed.

Organoleptic properties of bread sticks produced from wheat flour (72\%) and different levels of quinoa flour.

It is clear (Tables 6 and 7 )that bread stick of milled quinoa seeds recorded nearly the same sores as for quinoa flour sticks ,indicating that it is unnecessary to get rid of bran .Sticks of both types exceptionally nutritious food source, owing to their high level of 
protein, fatty acid, fiber, vitamin, mineral and micro constituents, phytosteroids carbohydrates possibly of low glycemic index.We are found that,The United National (UN) declared 2013 " the internationally of Quinoa " may due to its high nutrient value and potential to contribute to food security worldwide.

Table(1): The basic( control )formula used in the preparation of breadsticks

\begin{tabular}{c|c}
\hline Ingredients $(\mathrm{g})$ & Amount $(\mathrm{g})$ \\
\hline Wheat flour $72 \%$ & 100 \\
\hline Sugar & 8.00 \\
\hline Fat (oil) & 10 \\
\hline Salt & 0.5 \\
\hline Dry yeast & 0.6 \\
\hline
\end{tabular}

Table (2): The chemical composition of milled quinoa flour and wheat flour $72 \%$ (g $/ 100 \mathrm{~g}$ on dry weight basis)

\begin{tabular}{c|c|c}
\hline Component & Quinoa seed & Wheat flour 72\% \\
\hline Ether extract & 6.52 & 1.27 \\
\hline Crude protein & 13.13 & 11.85 \\
\hline Ash & 4.65 & 0.55 \\
\hline Total carbohydrate & 75.70 & 85.73 \\
\hline
\end{tabular}


Egyptian J. of Nutrition Vol. XXXV No. 2 (2020)

Table (3): Saturated fatty acids content of quinoa flour (\%g total fatty acids) .

\begin{tabular}{l|c|c|c}
\hline \multicolumn{1}{c|}{ Acids } & Symbol & \% of total fatty acids & $\begin{array}{c}\text { Concentrate of saturated fatty } \\
\text { acids g of lipid }\end{array}$ \\
\hline Tridecylic acid & C13:0 & 0.129 & 0.0084 \\
\hline Myristic acid & C14:0 & 0.309 & 0.02016 \\
\hline Pentadecanoic acid & C15:0 & 0.109 & 0.0071 \\
\hline Palmitic acid & C16:0 & 8.751 & 0.5702 \\
\hline Stearic acid & C18:0 & 34.432 & 2.2436 \\
\hline Arachidic acid & C20:0 & 0.857 & 0.0558 \\
\hline Total saturated & $\%$ & $44.587 \%$ & 2.9071 \\
\hline
\end{tabular}

Table (4): Unsaturated fatty acids content of quinoa flour (\%g total fatty acids)

\begin{tabular}{l|c|c|c}
\hline Acids & Symbol & $\begin{array}{c}\% \text { of total fatty } \\
\text { acids }\end{array}$ & $\begin{array}{c}\text { Concentrate of saturated fatty acids g of } \\
\text { lipid }\end{array}$ \\
\hline Oleic acid & C18:1 & 18.010 & 1.1735 \\
\hline Linoleic acid & C18:2 & 34.429 & 2.2434 \\
\hline Eicosenoic acid & C20:1 & 0.997 & 0.0649 \\
\hline Erucic acid & C22:1 & 1.058 & 0.0689 \\
\hline Docosadienoic acid & C22:2 & 0.919 & 0.0599 \\
\hline $\begin{array}{l}\text { Total Unsaturated fatty } \\
\text { acids }\end{array}$ & $\%$ & $55.413 \%$ & 3.6129 \\
\hline
\end{tabular}

Table (5): The chemical composition of breadsticks produced from wheat flour(72\% extraction) and different levels of milled quinoa flour.

\begin{tabular}{l|c|c|c|c|c}
\hline & $\begin{array}{c}\text { Nutrients } \\
\text { Quinoa and wheat flour }\end{array}$ & Ether extract & Ash & $\begin{array}{c}\text { Total } \\
\text { carbohydrate }\end{array}$ & $\begin{array}{c}\text { Energy } \\
\text { value(Cal/100g) }\end{array}$ \\
\hline 100 wheat & 11.75 & 1.25 & 0.55 & 86.45 & 404.05 \\
\hline $5 \%+95 \%$ & 11.92 & 1.51 & 0.75 & 85.82 & 404.55 \\
\hline $10 \%+90 \%$ & 11.98 & 1.79 & 0.97 & 85.26 & 405.07 \\
\hline $15 \%+85 \%$ & 12.04 & 2.06 & 1.17 & 84.73 & 405.62 \\
\hline $20 \%+80 \%$ & 12.11 & 2.32 & 1.37 & 84.20 & 406.12 \\
\hline
\end{tabular}


Lamia. M .Lotfy and Mona. E.M.Naga

Table (6): The sensory properties of bread sticks added to its surface are quinoa seeds produced from wheat flour $(72 \%)$ and different levels of quinoa flour.

\begin{tabular}{l|l|l|l|l|l}
\hline \multirow{2}{*}{ Samples } & \multicolumn{6}{|c|}{ Organoleptic characteristics } & \multicolumn{2}{c}{$\begin{array}{c}\text { Overall } \\
\text { Acceptability 10 }\end{array}$} \\
\cline { 2 - 6 } & Color 10 & Taste 10 & Flavor 10 & Texture 10 & 9.1 \\
\hline Control & 9.4 & 9.2 & 9.3 & 9.5 & 9.3 \\
\hline Quinoa flour 5\% & 8.7 & 8.3 & 8.5 & 8.2 & 8.4 \\
\hline Quinoa flour 10\% & 8.8 & 7.7 & 8.0 & 8.0 & 8.2 \\
\hline Quinoa flour 15\% & 8.4 & 8.1 & 7.7 & 8.0 & 8.3 \\
\hline Quinoa flour 20\% & 8.3 & 8.0 & 8.2 & 8.0 & 8.4 \\
\hline
\end{tabular}

Table (7): Organoleptic properties of bread sticks produced from wheat flour (72\%) and different levels of quinoa flour.

\begin{tabular}{l|c|c|c|c|c}
\hline \multirow{2}{*}{ Samples } & \multicolumn{6}{|l|}{ Organoleptic characteristics } & Texture 10 & $\begin{array}{c}\text { Overall } \\
\text { Acceptability 10 }\end{array}$ \\
\cline { 2 - 6 } Control & 9.3 & 9.4 & 8.9 & 8.9 & 9.0 \\
\hline $\begin{array}{l}\text { Quinoa } \\
\text { flour 5\% }\end{array}$ & 8.4 & 8.5 & 8.4 & 8.6 & 8.5 \\
\hline $\begin{array}{l}\text { Quinoa } \\
\text { flour 10\% }\end{array}$ & 8.3 & 8.6 & 8.4 & 7.9 & 8.3 \\
\hline $\begin{array}{l}\text { Quinoa } \\
\text { flour 15\% }\end{array}$ & 7.5 & 8.5 & 8.3 & 8.2 & 7.8 \\
\hline $\begin{array}{l}\text { Quinoa } \\
\text { flour 20\% }\end{array}$ & 7.7 & 7.8 & 8.4 & 8.0 & 7.8 \\
\hline
\end{tabular}


Egyptian J. of Nutrition Vol. XXXV No. 2 (2020)

\section{References}

A.O. A. C. (2000).

Association Official Analytical Chemists. Official methods of analysis $17^{\text {th }}$ ed Washington, DC., U.SA. Of quinoa (Chenopodium quinoa Willd.), J. Food

Abdullah, A. B., Fadle, J. A and Assaj, K. M. (2016).

Characteristics and Bread-Making qualityof wheat and quinoa flour blends. Assiut. J. Agric. Sci., 47(5):95-106.

Ballester-Sánchez, J.; Gil, J.V.; Haros, C.M.;Fernández-Espinar, M.T.(2019).

Effect of incorporating white, , red or blackquinoa flours on the total polyphenol content, antioxidant activity and colour bread.Plant Food Hum. Nutr. 74: 185-191.

Bhargava A, Shukla S, and Ohri D.(2013).

Genetic variability and heritability of selected traits during different cuttings of vegetable Chenopodium.Indian $\mathrm{J}$ : Genet.Plant . Breeding.; 63:359-360.

Calderell, V .A. S., Benassi, M, T., Visentainer, J. V and Matioli, G(2010).

Quinoa and flaxseed :Potential ingredient in the production of bread with functional quality.Braz.arch.biol.technol. 53 (4): 981-986. 
Chen YC, Tang $H$, Shimizu M, Watanabe $K$, and Mitsunaga T.(2012).

Food components in fractions of quinoa seed.Food Science and Technology Research.8:80-84.

Demir, M.K. (2014).

Use of quinoa flour in the production of gluten -free tarhana.Food Sc.Technal. Res 20: 1087-1092.

Demir, M.K. and Kilinc. M.(2017).

Utilization of quinoa flour in cookie production. Int.Food Res $\mathrm{J}$ 24(6): 2394-240.

Food Chem (2019) .

Quinia protein : compostion, structure and functional properties.Nov 30,299 : 125161. Doi: 10.1016/j.

Han, X., Shen, T. and Lou, H. (2007).

Dietary Polyphenols and Their Biological Significance. Int.J.Mol.Sc.8(9) : 950-988

Hirose Y, Fujita T, Ishii T and Ueno N.(2010) .

Antioxidative properties and flavonoid composition of Chenopodium quinoa seeds cultivated in Japan. Food Chem ; $119: 1300-1306$.

Masson, L. and Mella, M. A. (1985).

Materials grassas de consume habitual y Potential en Chile. (Ed. Universitaria), pp. 23. Santiago.\{ Minerals in quinoa (Chenopodium quinoa Willd.) seeds,\}

Miranda, M., Vega-Gálvez, A., Quispe-Fuentes, I Rodríguez, M.J., Maureira, H. and Martínez, E.A. (2012).

Nutritional aspects of six quinoa (Chenopodium quinoaWilld.) ecotypes from three geographical areas of Chile. Chilean Journal of Agricultural Research $72: 175-181$. 
Egyptian J. of Nutrition Vol. XXXV No. 2 (2020)

Oshodi AA, Ogungbenle HN, Oladimeji MO.(2013).

Chemical composition, nutritionally valuable minerals and functional properties of benniseed, pearl millet and quinoa flours. Int .J .Food. Sc. 50 : 325-331 Nutr.

Radwan, S. S. (1978).

Coupling of two dimension thin layer chromatography with gas chromatography for the quantitative analysis of lipids classes and their constituent fatty acids. J. Chrom. Sci., 16:538 -542.

Renzo, D. (1975).

Bakery products yeast leavened. Noyes Data Corporation. London, England.

Repo-Carrasco, R.; Espinoza, C. and Jacobsen, S.E.(2013).

Nutritional value and use of the Andean crops quinoa (Chenopodium quinoa) and kañiwa (Chenopodiumpallidicaule). Food Rev. Int. 19:179-189.

Repo-Carroso-Valencia RAM, Serna LA. (2011).

Quinoa (Chenopodium quinoa, Willd.) as a source of dietary fiber and other functional components. Ciencia E Tecnologia de Alimentos. 2011;31:225-230.

El Sohaimy, S.A., Mohamed, S.E., Shehata, ,M.G., Taha,A., Mehany .M. and Zaitoun, .M.A (2018).

Compositional Analysis and Functional Characteristics of Quinoa Flour. Article no. ARRB. 38435 .22(1):1-11.

Vega-Gálvez, A., Miranda, M., Vergara, J., Uribe, E., Puente, L. and Martínez, E.A.( 2010).

Nutrition facts and functional potential of quinoa (Chenopodium quinoa Wild.), an ancient Andean grain: a review. J.Sc.Food.Agric . 90:2541-2547 
Lamia. M .Lotfy and Mona. E.M.Naga

حبوب الكينوا لتحسين القيمة الغذائية والمكونات الوظيفية للبقسماط

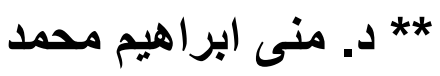

*د. لمباء محمود لطفي

* كلية التربية النوعية ـ قسم الاقتصاد المنزلي- جامعة كفر الثيخ

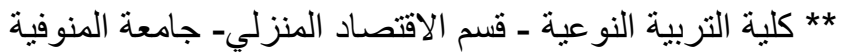

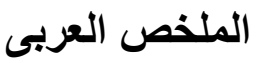

تم اجراء هذه الدراسة بهدف الحصول على عجائن محسنة ذات جودة عالية حيث نم

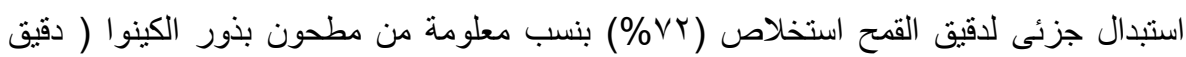

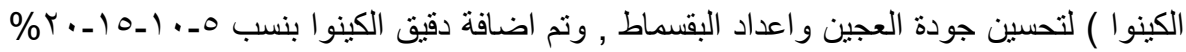
لاقيق القمح استخلاص (\%YY\%) . كما نم تقدير التركيب الكيماوى لدقيق الكينوا ودقيق القمح استخلاص (YYY\%) ومعرفة نسب الرطوبة والرماد والكربوهيدرات الكلية. وأيضا تم تحليل

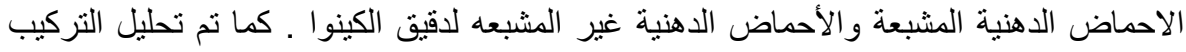

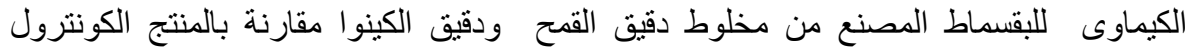

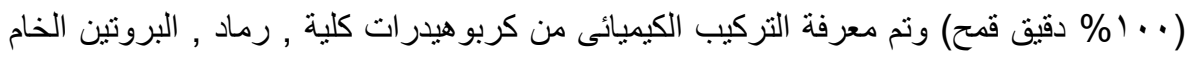

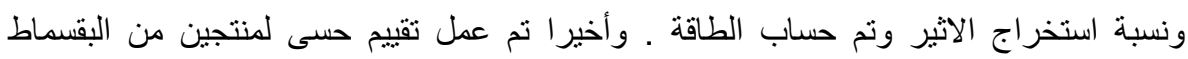

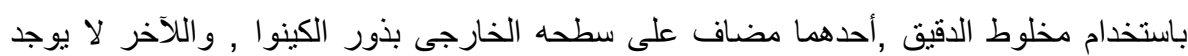

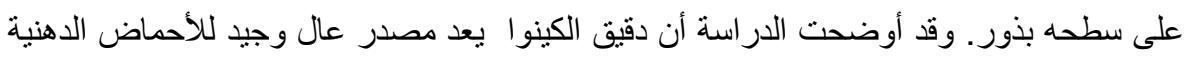

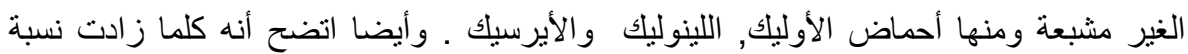

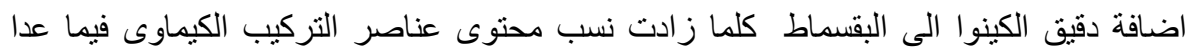

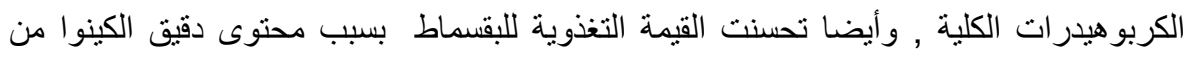
الأحماض الدهنية الغير مشبعه ـ وتوصى الدراسة باستخدام دقيق الكينوا فى العجائن لتحسين جودنها ورفع قيمتها الغذائية . 